\title{
EDITORIAL: \\ PANDEMI PENYAKIT MENULAR (COVID-19) HUBUNGAN INTERNASIONAL
}

Pada saat Volume 4 Nomor 2 jurnal ini terbit, situasi dunia tengah mengalami peristiwa yang sangat luar biasa, yaitu mewabahnya suatu penyakit menular yang mematikan. Salah satu penyakit infeksi saluran pernafasan menular yang disebabkan oleh virus corona novel SARS-CoV-2, dengan cepat telah berkembang menjadi pandemi global hanya dalam waktu dua bulan. World Health Organization (WHO) yang merupakan bagian dari PBB pada Maret 2020 mengumumkan nama virus itu sebagai Covid-19 beserta protokol penanggulangannya bagi negara-negara anggota. Tulisan ini sebagai tanda hirauan kami mengenai fenomena saat ini, khususnya mengenai penyakit menular dalam hubungan internasional.

Penyakit menular selama ini sebagai hirauan bidang penyelidikan kesehatan masyarakat (public health), ilmu pengetahuan alam (science), dan politik. Ruang lingkup kajiannya berkembang semakin luas seiring dengan semakin meluasnya penyebaran penyakit menular itu ke banyak wilayah di seluruh dunia. Permasalahan penyakit menular yang mengglobal menuntut solusi dan kerja sama internasional untuk mengatasinya. Negara-negara semakin diharapkan untuk serius dan menganggap penting pernyakit menular sebagai masalah kebijakan luar negeri. Masalah politik internasional dari penyakit menular ini kemudian muncul sebagai tantangan bagi studi Hubungan Internasional (Fidle, 1998). 
Istilah penyakit secara luas mengacu pada segala kondisi yang mengganggu fungsi normal tubuh. Penyakit adalah suatu kondisi abnormal tertentu yang secara negatif memengaruhi struktur atau fungsi semua atau sebagian dari suatu organisme yang disebabkan oleh faktor-faktor eksternal seperti patogen atau oleh disfungsi internal (Fidle, 1998). Pada manusia, penyakit sering digunakan secara lebih luas untuk merujuk pada kondisi apa pun yang menyebabkan rasa sakit, disfungsi, tekanan, masalah sosial, atau kematian pada orang yang menderita, maupun masalah serupa bagi mereka yang berhubungan dengan orang tersebut apakah sudah tertular atau tidak. Penyakit yang menular, yang juga dikenal sebagai penyakit yang dapat berpindah/transmisi (transmissible disease) atau penyakit yang dapat berkomunikasi (communicable disease) adalah penyakit akibat suatu infeksi yang dihasilkan dari keberadaan agen mikroba patogen, termasuk di antaranya adalah virus, bakteri, jamur, protozoa, organisme multiseluler, dan protein menyimpang yang dikenal sebagai prion. Penularannya (misalnya, influenza) melalui kontak fisik langsung dengan orang yang sakit maupun orang yang telah terinfeksi berupa sentuhan ataupun penyebaran tetesan dari bagian tubuhnya (droplet). Penyebaran lainnya melalui sekresi atau kontak tidak langsung seperti penularan melalui udara (airborne), benda yang terkontaminasi, makanan dan air minum, kontak orang dengan binatang, tempat penampungan hewan, gigitan serangga, dan tempat penampungan lingkungan adalah cara lain penularan penyakit menular. Penyakit menular menjadi sangat berbahaya jika obat atau vaksin penyembuhnya langka atau belum ditemukan, serta jumlah orang yang terinfeksi tidak stabil dan cenderung meningkat. Situasi penyakit menular menjadi permasalahan internasional bila penyebaran penularannya dari endemi, epidemi menjadi pandemi dengan tingkat infeksi yang tinggi semakin masif, sulit diprediksi dan tidak terkendalikan melewati perbatasan nasional, regional, benua dan dunia (Fidle, 1998).

Infeksi Covid-19 bukanlah penyakit pandemi yang pertama kali terjadi. Sebelum ini, dunia sudah melewati beberapa pandemi, seperti pandemi flu babi akibat virus H1N1 pada 2009. Kala itu, flu babi menginfeksi kurang lebih 1,4 miliar orang di seluruh dunia dan membuat ratusan ribu orang meninggal dunia. Lalu pada 1918-1920, dunia juga mengalami pandemi Spanish Flu yang diperkirakan menginfeksi 500 juta orang di seluruh dunia. Sementara itu, salah satu pandemi terburuk yang pernah tercatat dalam sejarah adalah pandemi Black 
Plague (The Plague) yang sering juga disebut sebagai Black Death. Pandemi ini telah menewaskan lebih dari setengah populasi benua Eropa kala itu (SaundersHastings \& Krewski, 2016).

Diskusi tentang penyakit, wabah penyakit menular dan segala hal yang berkaitan dengan cara penanggulangnnya semakin menjadi hirauan dari ragam ilmu, baik dari rumpun ilmu alam (nature science) dan rumpun ilmu sosial. Sumbangan nature science bagi menangani penyakit menular tidak terbantahkan. Dari rumpun ilmu ini, para ahli ilmu kedokteran dan farmasi, dengan patologi dan virologi di antaranya, adalah yang terdepan dalam menemukan dan mengidentifikasi segala jenis penyakit baru dan penularannya serta usaha pengobatannya. Ahli fisika menjelaskan seberapa lama virus penyakit bertahan terhadap panas, kelembaban, dan perubahan lingkungan lainnya. Ahli fisika kuantum telah memberikan cara-cara menjaga agar aliran energi tubuh manusia dapat melakukan self production dan self regeneration bagi penyembuhan. Ahli zoologi telah melihat kemungkinan agen penyakit menular yang berasal dari hewan kepada manusia (zoonosis) atau sebaliknya. Para ahli biologi telah meneliti sifat penularan penyakit terhadap tubuh manusia kelompok usia dan jenis kelamin yang paling rentan. Antropologi forensik telah mempertimbangkan berapa lama virus penyakit dapat bertahan daya tularnya sementara tubuh telah membusuk. Ahli teknologi komputer memberikan model simulasi penyebaran virus dan mendeteksi keberadaan orang-orang tertular. Ahli matematika telah menyediakan model pengamatan acak untuk mengidentifikasi penyebaran virus pandemi dan menawarkan beberapa kesimpulan yang serius (Shil, 2016).

Pada rumpun ilmu yang lain, ilmu-ilmu sosial tidak lagi berada di pinggiran ketika wabah penyakti melanda (Phua, 2009). Sosiologi telah menganalisis sosiabilitas dari penyakit menular sebagai suatu yang harus dihadapi manusia untuk hidup secara berdampingan selama obat penyembuh belum dapat ditemukan. Juga menyarankan agar jaga jarak sosial (social distancing) maupun jarak fisik (physical distancing) dan gaya hidup sehat diterapkan di lingkungan sosial baik di rumah dan di luar rumah. Ahli ilmu ekonomi telah dengan teliti memodelkan kebijakan makro dan mikro ekonomi yang optimal untuk suatu dunia dan wilayah negara yang terkontaminasi oleh virus. Ilmu politik tidak melulu berspekulasi 
dengan teori konspirasi mengenai dalang di balik dari merebaknya pandemi, namun mulai menangani respons kebijakan dan masalah tata kelola kepemerintahan pusat dan daerah yang lebih baik dan kontekstual terkait dengan penyakit. Studi gender telah menyelidiki dan memberikan rekomendasi kebijakan mengenai peran gender dalam morbiditas dan mortalitas pada pasien yang terserang virus penyakit menular (Jin, et al., 2020). Ahli ilmu komunikasi dan media telah menyediakan cara-cara komunikasi publik yang dapat dipahami dengan cepat dan mudah oleh ragam kalangan masyarakat perihal pandemi yang tengah merebak. Pandemi Covid-19 pada tahun 2020 ini tampaknya telah membantu menutup kesenjangan antarrumpun ilmu dalam menghadapi penyakit menular.

Kelangkaan studi Hubungan Internasional dalam mengkaji mengenai penyakit menular bukan hanya karena lebih fokus pada masalah konflik dan perang antarnegara. Dalam suatu perang sering penyakit menular ikut menyertai, baik secara sengaja atau tidak sengaja, sebagai senjata biologis untuk menghabisi musuh. Para filosof yang menginspirasi Hubungan Internasional menceritakan mengenai hal tersebut. Sun Tzu dalam The Art of War, menyebut suatu penyakit menular yang terjadi sebagai akibat dari sejumlah besar mayat busuk yang terbengkalai dapat menjadi amunisi baru tambahan. Dalam History of the Peloponnesian War, Thucydides telah memperingatkan akan adanya suatu wabah baru yang lain dari biasa, yang dapat mengarah pada pelanggaran hukum dan kekacauan secara umum. Menurutnya, yang kuat akan melakukan apa yang mereka bisa, dan yang lemah harus menderita disebabkan oleh wabah penyakit itu. Sementara state of nature dari Thomas Hobbes menggambarkan situasi anarki sistem internasional yang bisa berlaku kapan saja. Di dalam menghadapi sesuatu atau peristiwa yang menakutkan, negara-negara yang gagal bekerja sama dan segan untuk mengikuti protokol penanggulangan yang dianjurkan oleh otoritas supranasional, maka kekacauan internasional dapat terjadi yang memicu peningkatan keamananan mandiri (self-help system) untuk negara siap berperang (Viotti \& Kauppi., 2012, pp. 42-70).

Untuk menjadi hirauan kajian dalam Hubungan Internasional, setidaknya komunitas Hubungan Internasional mempunyai batasan atau definisi penyakit 
menular yang dikenali dan disepakati untuk digunakan. Namun sampai kini, sumber rujukan mengenai kesepakatan itu belum ditemui. Untuk merumuskan definisi tersebut beberapa kriteria perlu dipenuhi. Pertama, penyakit menular adalah apapun jenis agen mikroba patogen yang menginvensi dan okupasi atau menginfeksi tubuh manusia; agen mikroba patogen tersebut dapat berkembang menjadi varian baru yang menimbulkan gejala di kemudian hari. Kedua, penyakit menular tidak bisa dimusnahkan kecuali dijinakkan. Ketiga, setiap manusia yang terinfeksi belum pasti akan menjadi normal seperti sedia kala meskipun sehat. Keempat, dampaknya bersifat multidimensi yang menganggu dan mengancam stabilitas atau normalitas sosial, budaya, politik dan keamanan serta menggerogoti kondisi ekonomi bangsa dan dunia. Secara keseluruhan dampak besarnya dari penyakit menular kemungkinannya adalah perubahan total atau kepunahan suatu peradaban. Dari semua kriteria, pada intinya penyakit menular itu adalah sebuah anomali. Anomali yang berisi tantangan dan kesempatan yang harus dihadapi umat manusia dan juga seisi dunia bagi suatu perubahan. Komunitas Hubungan Internasional dapat berperan aktif dan menjadi agen perubahan yang berkontribusi untuk menghadapi anomali tersebut sesuai dengan kepakaran ilmu dan pengalamannya.

Dalam studi Hubungan Internasional modern, narasi kesehatan lebih popular daripada narasi penyakit menular, seperti yang ditemukan dalam kajian kebijakan luar negeri, diplomasi antarnegara dan kerja sama internasional. Globalisasi yang dipercepat telah menghasilkan perubahan nyata dalam tujuan dan praktik diplomatik. Masalah kesehatan telah menjadi semakin penting dalam agenda diplomasi global yang berkembang. Semakin banyak pemimpin di dunia akademis dan kebijakan yang berpikir tentang bagaimana menyusun dan memanfaatkan diplomasi untuk mencapai tujuan kesehatan global (global health).

Perihal diplomasi kesehatan publik atau kesehatan global yang secara substansi di antaranya mencakup isu penyakit menular, sepertinya perlu digeser untuk sementara. Saat ini, istilah diplomasi wabah penyakit menular lebih relevan dan lugas (straight to the point) untuk dikedepankan. Diplomasi yang terakhir ini ditujukan untuk mengedukasi pihak sasaran mengenai keberadaan penyakit menular yang sangat berberbahaya, dan mempromosikan cara hidup yang lebih 
berdamai namun waspada dalam menghadapinya. mendorong dan memotivasi pihak sasaran untuk menciptakan sistem keamanan sendiri senyaman dan sekreatif mungkin.

Diplomasi lain dapat tercipta pada masa krisis pandemi penyakit menular untuk tujuan meningkatkan soft power. Soft power secara luas meliputi kemampuan untuk membentuk preferensi pihak lain melakukan apa yang diinginkan dengan cara menarik dan kooptasi heart and mind melalui sumber-sumber budaya, nilai-nilai politik dan kebijakan luar negeri dari pada cara paksa melalui kekuatan koersif (Nye, 2004). Pandemi Covid-19 memberi kesempatan negara untuk memproyeksikan pengaruhnya. Dengan sumber yang dimiliki dan memanfaatkan media publik global dan media sosial, pemerintah suatu negara melakukan diplomasi soft power yang mempertunjukkan kemampuannya dalam merespons krisis pandemi di wilayahnya secara menarik. Jenis diplomasi publik baru yang melibatkan partisipasi warga dalam menghadapi bersama situasi yang bermasalah tampak lebih mengesankan dan mendapatkan aparesiasi khalayak pemirsa dan netizen dibandingkan strategi penghukuman sosial seperti "lock down". Diplomasi khusus (niche diplomacy) antarnegara bermunculan, seperti: 'diplomasi pandemi', 'diplomasi Covid', atau 'diplomasi masker (mask diplomacy)' yang menggeser diplomasi bantuan asing konvensional. Diplomasi khusus ini dapat dimanfaatkan oleh negara-negara manapun, terlepas dari ukuran besar dan kecilnya, atau kaya dan miskinnya, yang menunjukkan kemampuannya dalam berbagi sumber daya yang diperlukan dalam situasi krisis, seperti peralatan medis, dukungan profesional, alat uji dan masker wajah. Sebuah penelitian menunjukkan bahwa respons suatu negara terhadap krisis memengaruhi cara orang memandang kepemimpinan negara itu. Namun pelaku negara bukan satu-satunya variabel yang berpengaruh. Pandemi Covid-19 telah memberikan kesempatan kepada warga negara dan perusahaan dalam penciptaan soft power, serta kesempatan yang tidak biasa untuk memajukan identitas atau brand mereka sendiri, yang berkontribusi bagi negaranya dalam merancang solusi kreatif (Snyder \& Sindyukov, 2020).

Peran media komunikasi publik dan media sosial pada era digital masa kini sangat penting bagi penyebaran dan akses informasi secara instan dan efektif tentang soft power suatu negara dalam masa krisis pandemi. Negara-negara dapat memanfaatkan momen anjuran "stay at home" atau "work from home" di hampir seluruh dunia. Khalayak publik 
yang diam di rumah dan menghabiskan banyak waktu di depan layar televisi dan layar media digital (monitor), memungkinkan mereka dapat dengan cepat dan setiap saat dipengaruhi preferensinya. Negara-negara yang tidak mempertimbangkan kecenderungan kesempatan baik ini dapat menemukan diri mereka tertinggal begitu dunia ke luar dari pandemi. Lingkungan pasca-Covid-19 tentu akan terlihat berbeda kelak dalam berbagai cara, dan lanskap soft power yang berubah akan menjadi salah satunya.

Dalam kajian studi keamanan tradisional, ancaman eksternal terhadap negara adalah hirauan utama, termasuk di antaranya yang datang dari "the unknown" (UFO) dan penyakit yang dikembangkan oleh suatu pihak sebagai senjata militer (biowarfare). Sementara sedikit hirauan mengenai risiko dari suatu virus penyakit menular baru yang terbawa oleh arus globalisasi orang dan migrasi transnasional penduduk yang ancaman eksistensialnya bagi manusia dan alam semesta dapat melebihi ancaman senjata nuklir. Bahkan alat dan teknik tradisional tata negara seperti deterensi nuklir, sanksi ekonomi, pengawasan elektronik yang luas atau perundingan diplomatik akan sedikit berguna melawan musuh yang tidak terlihat ini. Sampai munculnya konsep keamanan manusia sebagai paradigma penting untuk memahami kerentanan global sebagai bagian dari perubahan yang melampaui masalah keamanan tradisional. Menurut paradigma ini, fokus utama keamanan haruslah manusia yang mencakup antara lain, keamanan kesehatan pribadi dan komunitas.

Hirauan tentang keamanan kesehatan manusia mencakup banyak hal yang saling berkaitan. Seperti hal lingkungan hidup yang berkaitan dengan kebersihan dan sanitasi, serta hal-hal kemampuan ekonomi setiap individu yang cukup berdaya secara edukasi untuk mandiri dalam memenuhi kebutuhan pangan dan tempat tinggal yang sehat. Namun untuk membebaskan setiap individu manusia di seluruh dunia dari ancaman bahaya penyakit menular alami ataupun nir-alami memerlukan perhatian khusus. Terutama efek yang didalilkan dari wabah penyakit menular yang belum ada vaksin penyembuhnya. Efek yang sangat mengerikan, tidak hanya berupa kematian manusia, tetapi juga mayat yang berinfeksi, serta stigma sosial bagi mereka yang terkait dan berkomunikasi dengan penyakit itu. Perihal penyakit menular melibatkan urusan dengan banyak patogen, yang masing-masing menimbulkan ancaman khusus bagi kesehatan masyarakat. Untuk itu upaya 
pencegahan dan pengendalian bahaya penyakit menular bagi setiap individu perlu diprioritaskan, terutama pada masa kini.

Dari kajian organisasi internasional, bagaimana WHO yang didirikan pada 1948, memberikan rekomedasi-rekomendasi terkait penjagaan kesehatan dan pencegahan suatu penyakit menular, serta bagaimana negara-negara anggota mengimplementasikannya. WHO digambarkan sebagai "penjaga kesehatan masyarakat global" yang tujuannya adalah kesehatan tertinggi yang mampu dicapai manusia, untuk semuanya. Pada 2005, WHO mengeluarkan Peraturan Kesehatan Internasional (International Health Regulations/IHR) baru yang menandai dimulainya era baru dalam sejarah upaya internasional untuk memerangi penyebaran penyakit menular. Peraturan ini menyediakan serangkaian langkah-langkah, khususnya pada tingkat negara, untuk mencegah dan mengatasi penyakit menular yang muncul dan baru muncul, serta meningkatkan kesehatan warga. Namun sifat dari peraturan yang dikeluarkan WHO lebih merupakan rekomendasi. Kebijakan negara yang diambil dalam merespons balik rekomendasi WHO akan memperhitungkan segala kemungkinan secara matang dengan pengetahuan yang komprehensif dan mendalam serta memperhitungkan konteks yang khas dan kemampuan sumber daya yang dimiliki. Selain itu, kebijakan preventif ataupun mitigasi apapun untuk menekan penyebaran penyakit perlu disertai dengan solusi alternatif untuk tidak menimbulkan masalah baru lainnya.

Selama 11 tahun terakhir, WHO telah menyelia respons global terhadap enam peritiwa darurat kesehatan global, termasuk wabah Ebola di Afrika Barat pada 2014, wabah Zika pada 2016 dan kini pandemi Covid-19. Rekomendasi WHO dalam menghadapi merebaknya Covid-19 dalam koordinasi respons global pandemi disebut sebagai ujian terbesar bagi dunia sejak Perang Dunia Kedua. Beberapa negara anggota dapat mengikuti rekomendasi WHO tanpa revisi, dengan revisi dan sebagian lagi mengkritisi. Perbedaan dalam menerima dan mengimplementasikan rekomendasi WHO adalah wajar mengingat pemerintah suatu negara lebih mengetahui apa yang terbaik bagi negaranya. Namun, bila disertai dengan maksud dan tujuan politik atau lainnya maka persoalan baru tercipta.

Melihat pada keadaan Teori Hubungan Internasional, penstudi dengan cepat menyadari tidak adanya konsensus teoritis tentang cara terbaik untuk memodelkan politik 
dunia yang dapat diterapkan pada dunia nyata. Terdapat beberapa paradigma yang mencoba menjelaskan hubungan internasional. Masing-masing paradigma memiliki pandangan yang berbeda tentang bagaimana menghadapi suatu kasus. Misalnya peristiwa wabah penyakit menular yang memengaruhi politik dunia dan perilaku para aktor politik internasional dalam menanggapi penderitaan. Salah satunya adalah paradigma realisme yang merupakan paradigma arus utama Hubungan Internasional tradisional, namun masih banyak penganutnya sampai kini.

Realisme memulai dengan asumsi bahwa anarki adalah kendala utama politik dunia dan tidak ada otoritas terpusat dan sah untuk mengendalikan negara. Setiap negara sebagai aktor utama harus mengadopsi langkah-langkah "swadaya" untuk memastikan keberlanjutan keberadaan dan keamanannya sebagai kepentingan nasional, dengan memaksimalkan kekuatan (power) yang dimiliki, terutama kekuatan militer. Setiap negara melakukan hal yang sama yang akan menjurus kepada situasi yang saling menyeimbangkan kekuatan (balancing of power) antarnegara. Kerja sama antarnegara dimungkinkan namun bersifat sementara dan tidak stabil dengan mempertimbangkan distribusi keuntungan (relative sum games atau zero-sum games). Distribusi yang menguntungkan sepihak, dan kemunculan negara hegemon serta kontra-hegemon, akan mengkibatkan dilema keamanan (security dilemma) dan keseimbangan menjadi goyah dengan perang bersenjata sebagai solusinya. Negara-negara yang kuat akan bertahan dan yang lemah akan tersingkirkan atau punah.

Berdasarkan pada asumsi realisme ini, dengan mengikuti logika bernalar Drezner (2015), dapat dijelaskan bagaimana pandemi virus penyakit menular (Covid-19) memengaruhi politik dunia. Menurut realisme, hubungan internasional sebagian besar tidak akan terpengaruh. Peristiwa pandemi penyakit menular merupakan wahana power play negara-negara status quo di dalam sistem internasional yang anarkis. Melalui pandemi hubungan kekuasaan yang ada diverifikasi. Negara yang menempati posisi powerfull dalam segala sumber, termasuk sistem kesehatannya telah menciptakan masyarakat yang lebih kuat dan kebal terhadap wabah penyakit, dan dinamis dalam menghadapi persoalan pandemi. Negara ini akan memperoleh bagian yang lebih besar dari power relatif selama pandemi. Sebaliknya yang terjadi bagi negara yang miskin dan lemah dalam sumber daya tidak mampu mengurangi banyak efek dari fenomena penyakit menular itu. 
Namun, kaum Realis mengakui kemungkinan terjadinya beberapa pergeseran pada distribusi kekuasaan global dalam peristiwa pandemi. Negara powerfull belum tentu dapat mempertahankan status quonya di dalam sistem internasional. Semua sumber daya yang dimiliki tidak menjamin keberhasilannya dalam mengukuhkan diri sebagai super power. Sebaliknya yang terjadi pada beberapa negara kecil dan lebih lemah, dan bahkan yang tidak diperhitungkan sebelumnya. Dengan sumber daya yang terbatas namun efektif dan tepat guna, negara ini muncul sebagai pemenang dalam memukul mundur virus mematikan dari pada negara lainnya. Bila demikian halnya, pergeseran struktur kekuasan dapat terjadi, namun karakter politik dunia belum tentu berubah. Pencarian negara atas power yang tak habis-habisnya akan terus berlangsung namun dengan cara yang berbeda. Pertama, dengan penggunaan soft power, yaitu negara mampu menaklukkan preferensi pihak lain dengan mempertunjukkan kemampuan inovasinya, keramahannya dalam berbagi, dan implementasi nilai-nilai kemanusiaan yang luhur dari masyarakatnya (saling tolong menolong, gotong royong, dan sebagainya). Kedua, dengan menggunakan hard power, yaitu negara mampu menaklukkan masyarakatnya di dalam negeri dan negaranegera lain secara koersif, berupa paksaan dan ancaman bersenjata, serta bayaran atau sogokan untuk mendukung negara itu menjadi yang pertama terbebas dari pandemi. Ketiga, dengan menggunakan smart power yaitu kemampuan gabungan dari kedua cara tersebut.

Realis juga memprediksi politik keseimbangan kekuasaan (balance of power). Dalam situasi pandemi, negara-negara dapat melakukan strategi koalisi antarnegara atau koalisi dengan virus penyakit untuk mereposisi kekuasaannya. Namun, koalisi ini tidak permanen dan ada selama keperluan pandemi. Koalisi terjadi secara alami adalah antarnegara yang berbatasan secara geografi untuk bekerja sama dalam membatasi ekspansi teritorial virus. Koalisi yang tidak alami tetapi sebagai strategi di masa pandemi digunakan untuk tujuan politik kekuasaan demi menambah kemampuan dan kepentingan nasional sendiri. Di antaranya adalah, koalisi sebagai prestise tanpa prestasi; koalisi untuk okupasi dan intervensi mitra yang lebih lemah atas nama keamanan bersama; dan koalisi untuk mendapatkan daerah penyangga (buffer zone), memadamkan gerakan iredentis, menyelesaikan masalah lama, atau menaklukkan lawan yang bertahan lama; dan yang terakhir, koalisi untuk mendapatkan laboratorium hidup bagi suatu percobaan atau penemuan anti-virus. 
Di sisi lain, negara-negara dapat melakukan koalisi dengan virus penyakit. Virus penyakit menular adalah makhluk hidup yang dapat berkembang dan bermutasi menjadi varian baru yang belum tentu dapat diidentifikasi dengan cepat oleh manusia. Alih-alih berdamai dengan virus pada tahap awal, untuk kemudian bekerja sama dalam menyukseskan strategi dan taktik negara untuk memperoleh lebih power di dalam sistem internasional yang anarki. Lebih dari itu menurut logika para realis, manusia membasmi virus adalah pekerjaan yang sia-sia. Seperti halnya manusia realis, virus memiliki hasrat bawaan untuk berkuasa dan tunduk pada 'aturan main' sistem anarki. Oleh karena itu, manusia berkoeksistensi dengan virus dalam suatu bentuk tata kelola kenormalan yang baru, yang pada masa kini disebut dengan istilah "the new normal".

INTERMESTIC Volume 4 Nomor 2 Tahun 2020 memuat satu artikel yang membahas mengenai pandemi virus penyakit yang berbahaya. "Ebola Virus in West Africa as National Security Threat to the United States of America", ditulis oleh Kemas Muhammad Zulfikar. Artikel ini menelaah alasan Amerika Serikat (AS) menjadikan virus Ebola yang menjadi pandemi di wilayah Afrika Barat sebagai prioritas keamanan nasional AS. AS menurunkan 3.000 pasukan tentaranya ke Liberia dan menerapkan strategi selective engagement ke wilayah-wilayah rentan koflik di Afrika Barat. Pandemi virus Ebola memberi kesempatan bagi AS untuk menerapkan kebijakan anti terorismenya di wilayah-wilayah rentan konflik di Afrika Barat sebagai antisipasi terhadap kemungkinan aksi dan pengembangan bioterorisme yang memanfaatkan virus pandemi di wilayah konflik.

Artikel-artikel berikutnya tidak berkaitan dengan pandemi penyakit menular. Artikel berjudul "Nigeria-China Bilateral Trade Relations: Is There Market Opportunities in China?" ditulis oleh Kabiru Hannafi Ibrahim, Dyah Wulan Sari, dan Rossanto Dwi Handoyo. Artikel ini mengenai peluang pasar bagi Nigeria dalam perekonomian Cina selama periode 1988-2017. Artikel berikut "Does The Single Draft of COC in The South China Sea Matters?" ditulis oleh Agus Haryanto dan Arief Bakhtiar Darmawan. Artikel ini menggunakan konsep International Dispute Settlement Procedures (IDSPS) untuk membahas mengenai aksi-aksi dari negara-negara pengklaim wilayah persengketaan di Laut Cina Selatan dalam upaya penyelesaiannya. Artikel selanjutnya "Turkey's Border Security Policy against Non-State Actors (2016-2019)", ditulis oleh Luerdi and Amri Hakim. Artikel ini membahas kebijakan keamanan 
perbatasan Turki yang mendasari Turki melancarkan serangkaian operasi militer untuk membersihkan Suriah Utara dari milisi-milisi Daesh dan PKK/PYD/YPG. Artikel terakhir "Hibridisasi Heavy Metal sebagai Lahirnya Metal Islam di Indonesia" di tulis oleh Anis Sujudi. Artikel ini menganalisis hibridisasi heavy metal dan Islam melalui band-band metal Islam yang lahir di Jakarta, Bandung dan beberapa tempat lainnya di Indonesia. Kehadiran metal Islam dalam skena metal, menurut penulis, mengubah pola komunitas, kebiasaan dan identitas dalam skema metal, dengan menerapkan nilai berdasarkan Islam.

Akhir kata, kami menghaturkan ucapan terima kasih tak terhingga atas kesediaan para mitra bestari dan para penulis dalam mewujudkan penerbitan e-Jurnal INTERMESTIC Volume 4 Nomor 2 pada Mei 2020 ini.

Hormat kami,

Arry Bainus dan Junita Budi Rachman

Pimpinan Redaksi dan Wakil Pimpinan Redaksi

\section{Daftar Pustaka}

Drezner, D. (2015). The Realpolitik of the Living Dead. Theories of International Politics and ZombiesL Reviewed Edition, 37-50.

Fidle, D. P. (1998). Microbialpolitik: Infectious Diseasu and International Relations. American University International Law Review, 14(1), 1-53.

Jin, J.-M., Bai, P., He, W., Wu, F., Liu, X.-F., Han, D.-M., . . Y Yang, J.-K. (2020). Gender Differences in Patients With COVID-19: Focus on Severity and Mortality. Frontiers in Public Health, 8(15). doi:doi.org/10.3389/fpubh.2020.00152

Nye, J. S. (2004). Soft Power : the Means to Success in World Politics. . New York: Public Affairs.

Phua, K.-L. (2009). Fighting the Battle Against Infectious Diseases: Contributions of Selected Social Science Disciplines. Infectious Diseases: Research and Treatment, $\quad 2, \quad 5-9 . \quad$ Retrieved from https://www.researchgate.net/deref/http\%3A\%2F\%2Fwww.la-press.com\%2F

Saunders-Hastings, P. R., \& Krewski, D. D. (2016). Reviewing the History of Pandemic Influenza: Understanding Patterns of Emergence and Transmission. Pathogens, 5(66), 1-19. doi:10.3390/pathogens5040066 
Shil, P. (2016). Mathematical Modeling of Viral Epidemics: A Review. Biomedical Research Journal , 3(2), 195-215. doi:10.4103/2349-3666.240612

Snyder, A., \& Sindyukov, M. (2020, April 16). Global Opinion. Dipetik May 25, 2020, dari Diplomatic Courier: https://www.diplomaticourier.com/posts/how-covid-19is-changing-the-soft-power-game

Viotti, P. R., \& Kauppi., M. V. (2012). International relations theory. Boston: Longman. 